\title{
Parasite-associated mortality of juvenile Pacific salmon caused by the trematode Nanophyetus salmincola during early marine residence
}

\author{
Kym Corporon Jacobson ${ }^{1, *}$, David Teel ${ }^{2}$, Donald M. Van Doornik ${ }^{2}$, \\ Edmundo Casillas ${ }^{3}$
}

${ }^{1}$ NOAA Fisheries, Northwest Fisheries Science Center, Hatfield Marine Science Center, 2030 South Marine Science Drive,
Newport, Oregon 97365, USA
${ }^{2}$ NOAA Fisheries, Northwest Fisheries Science Center, Manchester Research Laboratory, 7305 East Beach Drive,
Port Orchard, Washington 98366, USA
${ }^{3}$ NOAA Fisheries, Northwest Fisheries Science Center, 2725 Montlake Boulevard East, Seattle, Washington 98112, USA

\begin{abstract}
The potential effect of the freshwater trematode Nanophyetus salmincola on early marine survival of Pacific salmon was assessed by monitoring the prevalence and intensity of metacercarial infection in yearling coho salmon Oncorhynchus kisutch, and yearling and subyearling Chinook salmon O. tshawytscha caught off Oregon and Washington during May, June, and September of 1999 to 2002. Annual prevalences of N. salmincola infection in yearling coho salmon were 62 to $78 \%$ and were significantly greater each year than in both yearling and subyearling Chinook salmon (19.3 to $53.8 \%$ and 40.5 to $53.5 \%$, respectively). Yearling coho salmon also had significantly higher intensities of infection (from approximately 2-fold to 12-fold) than yearling and subyearling Chinook salmon. Prevalences and intensities in coho salmon caught in September were significantly lower (by approximately $21 \%$ ) than in coho salmon caught in May or June in 3 of the 4 years. Variance to mean ratios of parasite abundance in coho salmon were also lowest in September, suggesting parasiteassociated host mortality during early ocean residence. There was no evidence for a seasonal decline in infection in yearling or subyearling Chinook salmon. Infection intensities, but not prevalences, were significantly greater in naturally produced (wild) coho salmon than in hatchery produced coho salmon and could be due to differences in exposure to the trematode. Highly infected naturally produced coho salmon were not caught in September. This study suggests that coho salmon with high intensities of $N$. salmincola may not survive early marine residence, and that disease processes need to be considered as a factor affecting marine survival of juvenile salmon.
\end{abstract}

KEY WORDS: Parasite $\cdot$ Chinook salmon $\cdot$ Coho salmon · Ocean mortality $\cdot$ Nanophyetus salmincola

\section{INTRODUCTION}

The importance of the early marine phase to the success of Pacific salmon runs highlighted by Pearcy (1992) has become more evident with documented correlations between ocean conditions and returning adult run sizes (Logerwell et al. 2003, Scheuerell \& Williams 2005). In fact, Van Doornik et al. (2007) reported that densities of Columbia River yearling coho salmon On- corhynchus kisutch caught off the Oregon and Washington coasts in September from 1998 to 2005 were strongly correlated with adult abundances the following year, indicating that year class strength for that species was largely determined during the first summer in the ocean. As such, the factors that may affect growth and survival of Pacific salmonids during the initial months at sea are receiving increased attention from scientists and fishery managers. 
Both bottom-up (food availability and quality) and top-down (predation) processes have been noted as important contributors to early ocean mortalities of Pacific salmon (Pearcy 1992, Emmett et al. 2006). Like predators, pathogens can also play significant roles in regulating wild populations (Scott \& Dobson 1989, Hudson et al. 1998). Several pathogens have been reported to cause mortality of Pacific salmon in hatcheries (Fryer \& Sanders 1981), and as returning adults (Kocan et al. 2004), but the quantitative effect of pathogens on Pacific salmon survival in the ocean remains unknown (Pearcy 1992). The rapid disappearance of weakened and dead fish makes measuring the effects of pathogens on fish populations in the marine environment extremely difficult. Fish hosts of known infection status in the wild can not be routinely followed, and heavily infected hosts likely die and disappear before they can be detected (Gordon \& Rau 1982, Bakke \& Harris 1998). However, methods for estimating mortality due to parasitism in wild fish populations have been described (Anderson \& Gordon 1982, Lester 1984) and tested, both theoretically (Rousset et al. 1996, Duerr et al. 2003) and in natural populations (Kennedy 1984, Kalbe et al. 2002, Bourque et al. 2006). For example, indirect evidence for parasite-induced mortality in wild fish populations has been based upon observed age-intensity or age-abundance curves and declines in parasite dispersion (the variance to mean ratio of parasite abundance) over time (Gordon \& Rau 1982, Kalbe et al. 2002).

Pacific salmon serve as an intermediate host for the freshwater trematode Nanophyetus salmincola, a parasite documented to cause significant losses of Pacific salmon fry (Milleman \& Knapp 1970) and to increase disease susceptibility of Chinook salmon smolts (Jacobson et al. 2003). The first intermediate host of the parasite is a freshwater snail, Juga plicifera, common in streams and rivers from northern California through western Washington (Simms et al. 1931). Juvenile salmonids become infected in freshwater by penetration of cercariae that have emerged from the snails. The metacercarial stage of $N$. salmincola can encyst in most fish tissues with greatest abundance in muscle and kidney (Simms et al. 1931). The parasites are not cleared by the fish host, and remain viable throughout the life of the salmon (Farrell et al. 1964), ultimately maturing and releasing eggs in piscivorous birds and mammals (Millemann \& Knapp 1970).

The prevalence of Nanophyetus salmincola in juvenile Chinook salmon Oncorhynchus tshawytscha and coho salmon in Pacific Northwest estuaries can be very high, ranging from 33 to $100 \%$ in subyearling Chinook salmon and from 73 to $98 \%$ in yearling coho salmon (Arkoosh et al. 2004). Reports of infection prevalence in adult salmon caught off Oregon have been much lower. Weiseth et al. (1974) reported prevalences of $31 \%$ in adult Chinook salmon and $53 \%$ in adult coho salmon. Olson (1978) reported a prevalence of $13 \%$ in adult Chinook salmon and $5 \%$ in adult coho salmon. The substantial difference in prevalences observed between estuarine smolts and ocean-caught adults could be due to differential mortality associated with parasitic infection during ocean residence.

With numerous salmon populations in the Pacific Northwest listed as threatened or endangered under the Endangered Species Act (NMFS 2005), the most comprehensive understanding possible of the factors that affect salmon survival is imperative for the development of effective recovery plans. In this study we examined the dynamics of Nanophyetus salmincola infection and associations with metrics of growth and condition in juvenile coho salmon and Chinook salmon caught during their initial months at sea to determine the parasites' potential contribution to ocean mortality of juvenile Pacific salmon.

\section{MATERIALS AND METHODS}

Sampling efforts. This study is one component of a multidisciplinary project designed to examine the early ocean ecology of juvenile Pacific salmonids and the factors that affect their marine survival. Data presented here are from juvenile salmon collected in the ocean during May, June, and September from 1999 to 2002. Sampling typically occurred during $10 \mathrm{~d}$ in the second half of the month. Sampling stations in May were located primarily along 5 transects in 1999, ranging from La Push, Washington $\left(47^{\circ} 55^{\prime} \mathrm{N}\right)$ to Newport, Oregon $\left(44^{\circ} 44^{\prime} \mathrm{N}\right)$, and along 3 transects in 2000 to 2002, ranging from Grays Harbor, Washington $\left(47^{\circ} 00^{\prime} \mathrm{N}\right)$ to Cape Meares, Oregon $\left(45^{\circ} 29^{\prime} \mathrm{N}\right)$ (Fig. 1). Sampling stations in June and September were located on 8 to 10 transects, ranging from La Push to Newport. Stations on each transect began as close to shore as possible (minimum fishing depth of $30 \mathrm{~m}$ ) and continued at approximately $9 \mathrm{~km}$ increments to just beyond the shelf break (generally $50 \mathrm{~km}$ offshore).

Juvenile salmon were collected during daylight hours using a Nordic ${ }^{1}$ 264-rope trawl (NET Systems) fished at the surface. The mouth opening of the trawl was $20 \mathrm{~m}$ deep and $30 \mathrm{~m}$ wide when towed. Mesh sizes ranged from $162.6 \mathrm{~cm}$ in the throat of the trawl near the jib lines to $8.9 \mathrm{~cm}$ in the cod end. To maintain catches of small fish and squid, a $6.1 \mathrm{~m}$ long, $0.8 \mathrm{~cm}$ mesh knotless liner was sewn into the cod end. Tows lasted for

${ }^{1}$ Reference to trade names does not imply endorsement by the National Marine Fisheries Service 




Fig. 1. Sampling stations (-) located off Oregon and Washington, USA, where surface trawls were conducted to collect juvenile salmonids. Dashed line: $180 \mathrm{~m}$ depth contour (i.e. the shelf break)
$30 \mathrm{~min}$ at an approximate speed of $6.5 \mathrm{~km} \mathrm{~h}^{-1}$ unless large catches seemed probable, then trawls were reduced to $15 \mathrm{~min}$. Juvenile salmon were identified, counted, measured to the nearest mm fork length (FL) and immediately frozen for later analysis.

In the laboratory, juvenile salmon were partially thawed, re-measured for FL, weighed to the nearest gram, and species identities were confirmed. Salmon were also scanned for internal tags, external hatchery markings (e.g. adipose fin clips), and coded wire tags. Based upon the high percentage of hatchery salmon that were marked during the 4 yr period (approximately 72 to $74 \%$ of all hatchery fish recorded by the Pacific States Marine Fisheries Commission Regional Mark Processing Center, Portland, OR), we used the presence and absence of any hatchery markings as a surrogate for hatchery versus naturally produced salmon for some analyses. We acknowledge that unmarked salmon were a combination of both naturally and hatchery produced salmon. We used salmon size criteria from previous studies (Dawley et al. 1985, Fisher \& Pearcy 1995) to classify juvenile salmon as subyearling or yearling and to exclude older year classes of salmon. Because most subyearling Chinook salmon enter the ocean after our June sampling effort, monthly comparisons of infection in these salmon were not justified. Coho salmon do not enter the ocean as subyearlings.

For detection and enumeration of metacercariae of Nanophyetus salmincola, the posterior half of each kidney was removed, placed in a labeled whirlpak bag, and refrozen. Since the entire skeletal muscular system can not be effectively examined, the posterior kidney has become a recognized surrogate site for measuring infection due to consistently high concentrations of metacercariae (Weiseth et al. 1974, Olson 1978). At a later date the kidney was compressed between 2 glass plates while still in the whirlpak bag and the encysted metacercariae were counted at 100x under a dissecting microscope.

Parasitological terms follow Bush et al. (1997); 'prevalence' is the percent of a host sample infected, and 'intensity' is the number of parasites in an infected host. The degree of parasite dispersion among hosts was determined by the variance to mean ratio $\left(\mathrm{s}^{2} / \bar{X}\right)$, calculated by dividing the sample variance by the sample mean of abundance (number of metacerariae in a host sample divided by the total number of hosts examined, including uninfected hosts). Declines in this ratio over time in a group of hosts have been used as a qualitative indication of parasite-associated mortality (Gordon \& Rau 1982, Kalbe et al. 2002).

Genetic analyses. Because differences in source populations of juvenile salmon could contribute to observed differences in Nanophyetus salmincola infections, individual coho salmon were assigned to their 
most likely region of origin using genetic stock identification techniques as described by Van Doornik et al. (2007). Fish were assigned to one of 4 regions: Northern California (north of Punta Gorda)/Oregon, Columbia River, Washington coast, and Puget Sound. The baseline data used to make the assignments consisted of allele frequencies for 11 microsatellite DNA loci previously shown to provide accurate individual assignment estimates for coho salmon caught off the coast of Oregon and Washington (Van Doornik et al. 2007).

Statistical analyses. The Fisher's exact test was used to test for differences in prevalence of the parasite, and a bootstrap 2-sample $t$-test was used to compare mean intensities. The statistical program Quantitative Parasitology 3.0 (J. Reiczigel \& L. Rózsa 2005, Budapest; distributed by the authors at www.behav.org/qp/ qp.htm) was used for these analyses and for calculation of confidence intervals.

\section{RESULTS}

\section{General patterns of infection}

Annual prevalence of Nanophyetus salmincola in yearling coho salmon caught off Oregon and Washington ranged from $62 \%$ in 1999 to $78 \%$ in 2001 (Table 1). Mean intensity of $N$. salmincola metacercariae in yearling coho salmon ranged from $142.1(95 \% \mathrm{CI}=$

Table 1. Nanophyetus salmincola infecting Oncorhynchus kisutch and O. tshawytscha. Annual prevalences and intensities (with 95\% confidence intervals) of metacercariae in juvenile salmon caught off Oregon and Washington, USA. $\mathrm{N}=$ total number of salmon examined

\begin{tabular}{|c|c|c|c|}
\hline Year & $\mathrm{N}$ & Prevalence & $\begin{array}{l}\text { Mean intensity } \\
\qquad(95 \% \mathrm{CI})\end{array}$ \\
\hline \multicolumn{4}{|c|}{ Yearling coho salmon $O$. kisutch } \\
\hline 1999 & 395 & $62.0 \%$ & $142.1(111.1-188.9)$ \\
\hline 2000 & 494 & $69.4 \%$ & $175.4(142.9-216.4)$ \\
\hline 2001 & 568 & $78.0 \%{ }^{\mathrm{a}}$ & $182.7(154.4-215.8)$ \\
\hline 2002 & 603 & $64.0 \%$ & $209.8(176.0-249.5)^{\mathrm{b}}$ \\
\hline \multicolumn{4}{|c|}{ Yearling Chinook salmon $O$. tshawytscha } \\
\hline 1999 & 491 & $19.3 \%$ & $18.0(12.9-25.7)$ \\
\hline 2000 & 304 & $30.9 \%$ & $72.9(43.9-122.0)$ \\
\hline 2001 & 132 & $53.8 \%{ }^{\mathrm{c}}$ & $25.6(15.7-44.3)$ \\
\hline 2002 & 328 & $49.4 \%{ }^{\mathrm{c}}$ & $25.8(19.3-35.8)$ \\
\hline \multicolumn{4}{|c|}{ Subyearling Chinook salmon $O$. tshawytscha } \\
\hline 1999 & 378 & $40.5 \%$ & $24.9(17.3-37.1)$ \\
\hline 2000 & 206 & $42.7 \%$ & $20.4(11.1-40.9)$ \\
\hline 2001 & 213 & $53.5 \%{ }^{\mathrm{a}}$ & 20.1 (12.0-36.9) \\
\hline 2002 & 380 & $42.6 \%$ & $17.1(11.8-24.5)$ \\
\hline \multicolumn{4}{|c|}{$\begin{array}{l}\text { aSignificantly different from all other years. }{ }^{\text {b}} \text { Significantly } \\
\text { different from 1999. 'Significantly different from } 1999 \\
\text { and } 2000\end{array}$} \\
\hline
\end{tabular}

$111.1-188.9)$ in 1999 to $209.8(95 \%$ CI $=176.0-249.5)$ in 2002 (Table 1). There was a significant difference in mean intensities between 1999 and 2002 (bootstrap $t$-test, $\mathrm{p}=0.01$ ), but not between any of the other years.

Prevalences of Nanophyetus salmincola in both yearling and subyearling Chinook salmon were significantly lower (Fisher's exact test, $\mathrm{p}<0.01$ ) each year than those observed in yearling coho salmon. The annual prevalences in yearling Chinook salmon ranged from $19.3 \%$ in 1999 to $53.8 \%$ in 2001 (Table 1) and were significantly higher in 2001 and 2002 than in 1999 and 2000 (Fisher's exact test, p < 0.01). Prevalences in subyearling Chinook salmon ranged from $40.5 \%$ in 1999 to $53.5 \%$ in 2001 . The prevalence in 2001 was significantly higher (Fisher's exact test, $\mathrm{p}<$ 0.05 ) than any other year (Table 1).

The mean intensities of Nanophyetus salmincola metacercariae in both yearling Chinook salmon and subyearling Chinook salmon were approximately 50 to $12.5 \%$ of the mean intensity in coho salmon each year of the study (Table 1). Mean intensities of metacercariae in yearling Chinook salmon ranged from 18.0 $(95 \% \mathrm{CI}=12.9-25.7)$ in 1999 to $72.9(95 \% \mathrm{CI}=$ 43.9-122.0) in 2000, but were not statistically different. Mean intensities in subyearling Chinook salmon ranged from $17.1(95 \% \mathrm{CI}=11.8-24.5)$ in 2002 to 24.9 $(95 \% \mathrm{CI}=11.1-40.9)$ in 1999 , and were also not statistically different.

\section{Monthly patterns of infection}

Prevalence of Nanophyetus salmincola in juvenile coho salmon caught in September was significantly less (Fisher's exact test, p < 0.01), by at least $21 \%$, than in May or June for 3 of the 4 years examined (Fig. 2a). Prevalences measured in May and June were not significantly different from each other in any of the years examined. Monthly prevalences in 2001 followed the same trend as other years, but the lower prevalence observed in September 2001 was not statistically different from May or June.

We observed significant differences in mean intensities of infection in coho salmon between months in each year except 2002 (Fig. 2b). In 1999 and 2001, mean intensities in September were significantly less than in June (bootstrap $t$-test, $\mathrm{p}=0.002$ and $\mathrm{p}<0.02$, respectively), and in 2000 the mean intensity in June was significantly less than in May (bootstrap $t$-test, $\mathrm{p}=0.04$ ). In 2000 the mean intensity in September was also lower than in May; however, there was a large variance around the mean in September, and the mean was not statistically different from either May or June 2000.

Prevalences of infection in yearling Chinook salmon (Fig. 3a) were not lower in September compared to 

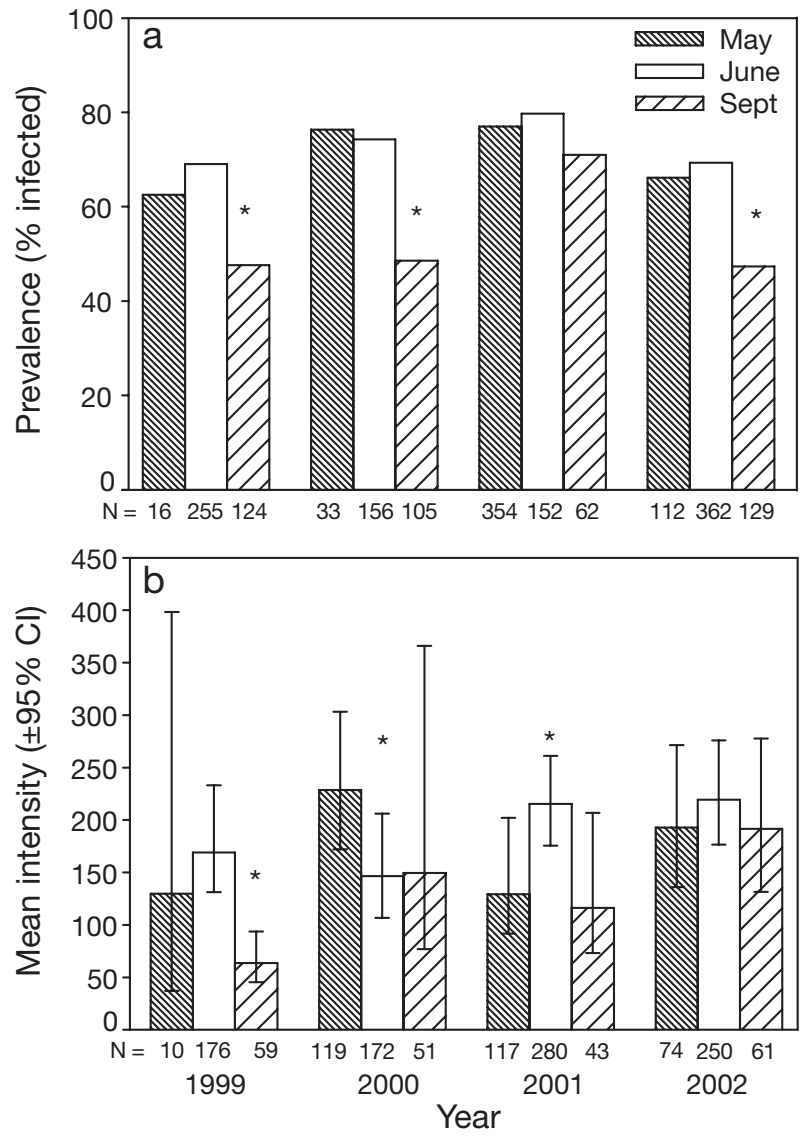

Fig. 2. Nanophyetus salmincola infecting Oncorhynchus kisutch. (a) Prevalences and (b) mean intensities of metacercariae in yearling coho salmon caught off Washington and Oregon, USA. $\mathrm{N}$ = number of coho salmon examined for each sampling period. ${ }^{*}$ Statistical differences $(p<0.05)$ between months within a year

either June or May in any year. A monthly difference in the intensity of infection in yearling Chinook salmon was observed only in 2002 when both June and September had significantly lower intensities than May (bootstrap $t$-test, $\mathrm{p}=0.05$ and $\mathrm{p}=0.02$, respectively) (Fig. 3b). There were too few subyearling Chinook salmon caught in May or June during all years to compare with September; thus, no monthly comparisons are shown.

\section{Marked vs. unmarked salmon}

To determine potential differences in Nanophyetus salmincola infections between hatchery produced and naturally produced salmon we separated fish by the presence or absence of any hatchery markings. The only significant difference in prevalence of the parasite between marked and unmarked coho salmon was in June 2000 (Fisher's exact test, $\mathrm{p}=0.01$ ) when the preva-
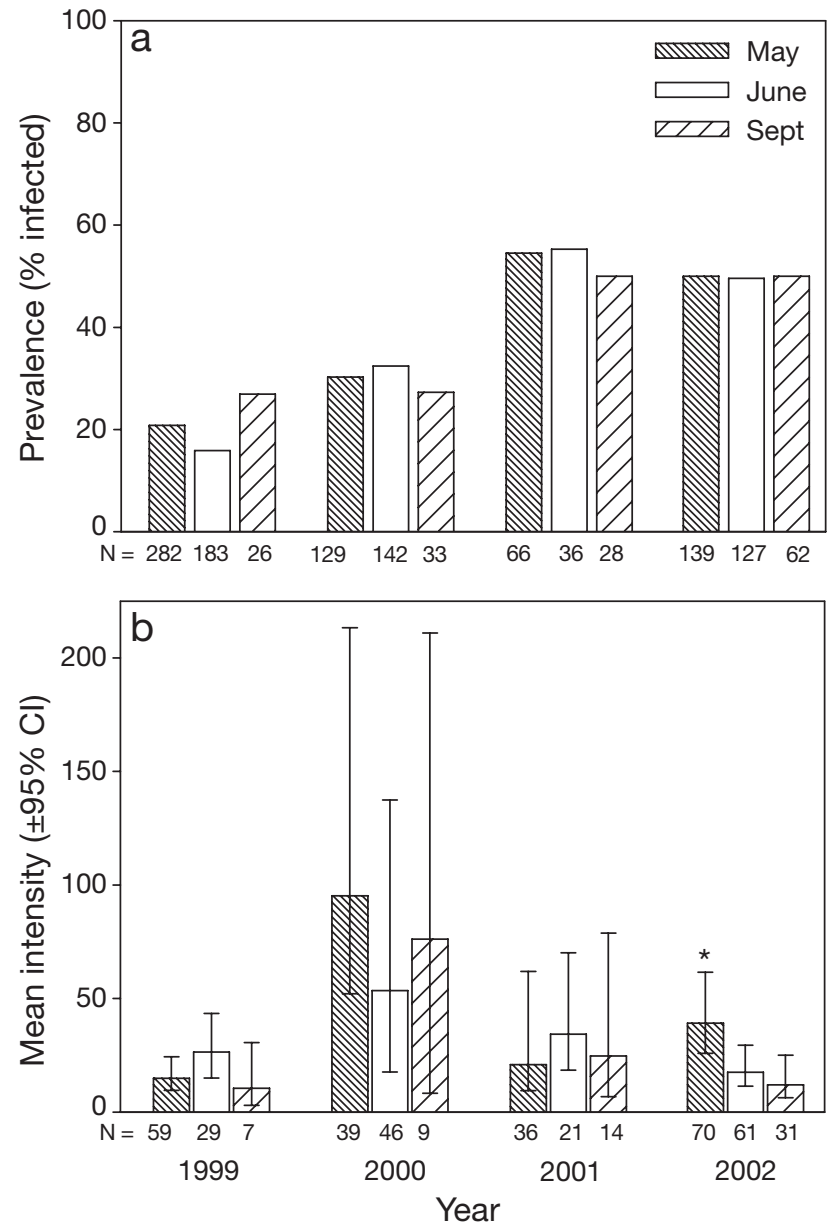

Fig. 3. Nanophyetus salmincola infecting Oncorhynchus tshawytscha. (a) Prevalences and (b) mean intensities of metacercariae in yearling Chinook salmon caught off Washington and Oregon, USA. N = number of salmon examined for each sampling period. ${ }^{*}$ Statistical differences $(p<0.05)$ between months within a year

lence in unmarked coho salmon was $53 \%$ (Fig. 4a) compared to $81 \%$ in marked coho salmon (Fig. 4b). For both marked and unmarked coho salmon, prevalences of $N$. salmincola in September were approximately $21 \%$ less than observed in May or June (Fisher's exact test, $\mathrm{p}<$ 0.05) in all years except 2001 (Fig. 4). In 2001, the prevalences in both groups of coho salmon were only 8 to $9 \%$ less in September than in May or June. Also in 2001, the prevalence of the parasite in unmarked coho salmon in June was significantly greater than in May (Fisher's exact test, $\mathrm{p}<0.005$ ) (Fig. 4a).

In contrast to the prevalence of infection, mean intensities of metacercariae were significantly higher (bootstrap $t$-test, $\mathrm{p}<0.01$ ) in unmarked coho salmon (Fig. 5a) than in marked coho salmon (Fig. 5b). Monthly mean intensities ranged from 61 to 380 metacercariae in unmarked coho salmon (Fig. 5a), and from 33 to 155 metacercariae in marked coho salmon 


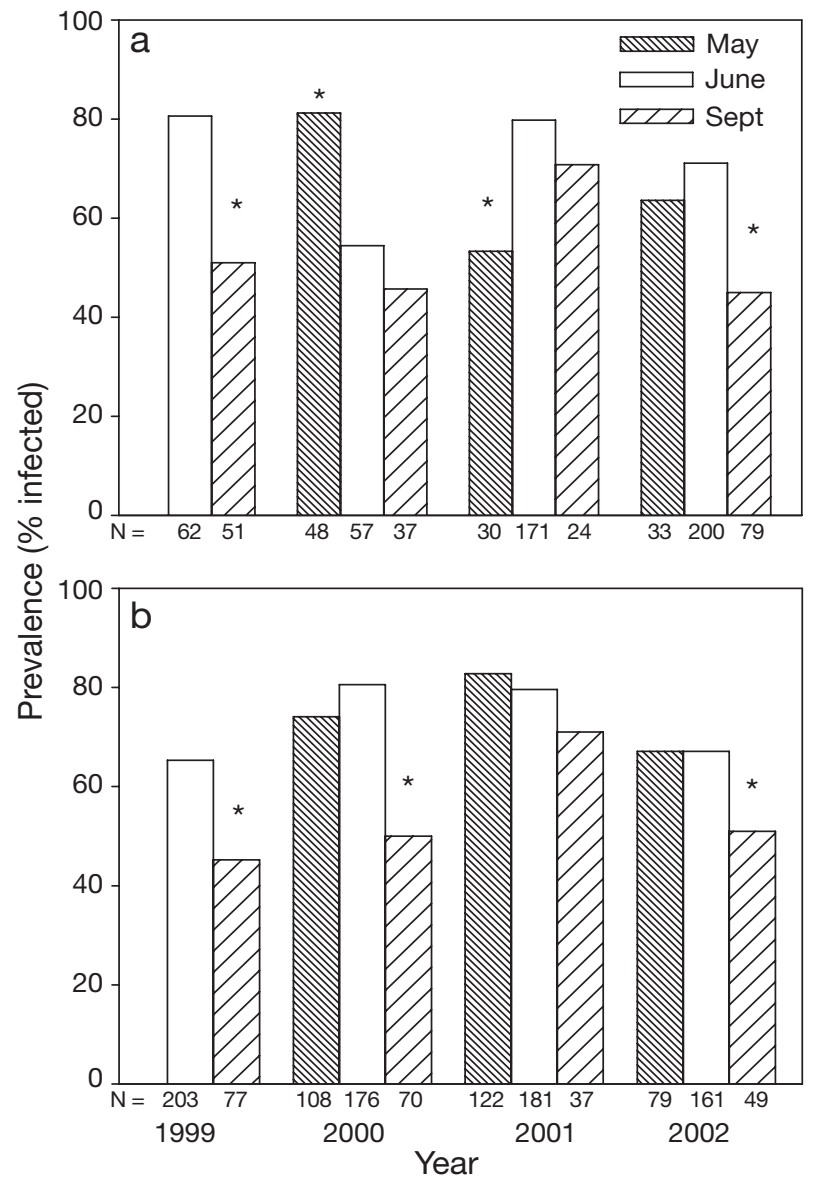

Fig. 4. Nanophyetus salmincola infecting Oncorhynchus kisutch. Prevalences of metacercariae in (a) unmarked and (b) marked yearling coho salmon caught off Washington and Oregon, USA. Marked salmon include salmon with any type of hatchery marking including clipped fins, coded-wire tags, PIT-tags, or colored latex markings. $\mathrm{N}=$ number of salmon examined for each sampling period. ${ }^{*}$ Statistical differences $(p<0.05)$ between months within a year

(Fig. 5b). In 1999 and 2001 the number of Nanophyetus salmincola metacercariae in unmarked coho salmon in September was significantly less (bootstrap $t$-test, $\mathrm{p}<$ 0.05) than in June (Fig. 5a). Mean intensities in unmarked coho salmon in September of 2000 and 2002 were also lower than in June but were not significantly different. In marked coho salmon, there was a significant difference (bootstrap $t$-test, $\mathrm{p}=0.056$ ) in mean intensity of metacercariae between June and September in 1999 only (Fig. 5b).

The only difference (Fisher's exact test, $\mathrm{p}<0.05$ ) found between unmarked and marked yearling Chinook salmon was the prevalences of Nanophyetus salmincola in 1999 and in 2000 (Fig. 6). There were no differences in prevalence or mean intensity of the parasite between unmarked and marked subyearling Chinook salmon in any year (data not shown). Catches of Chinook salmon were



Fig. 5. Nanophyetus salmincola infecting Oncorhynchus kisutch. Mean intensities of metacercariae in (a) unmarked and (b) marked yearling coho salmon caught off Washington and Oregon, USA. Marked salmon include salmon with any type of hatchery marking including clipped fins, coded-wire tags, PIT-tags, or colored latex markings. $\mathrm{N}=$ number of salmon examined for each sampling period. * Statistical differences $(p<0.05)$ between months within a year

not large enough each month to separate the data by both month and hatchery markings.

To further identify possible parasite-associated mortality of coho salmon during early marine residence, the variance to mean ratio of infection (a measure of parasite dispersion) was calculated for each month. The variance to mean ratio declined seasonally, with highest values in either May or June and lower values in September (Fig. 7). This trend was observed in unmarked coho salmon (Fig. 7a) in all years and in marked coho salmon (Fig. 7b) in all years except 2000.

Several metrics of growth and condition were examined to identify measurable effects of Nanophyetus salmincola infection on juvenile coho salmon (data not shown). However, no consistent patterns were identified with prevalence or intensity of infection and salmon fork length, weight, or Fulton's condition index (weight/ 


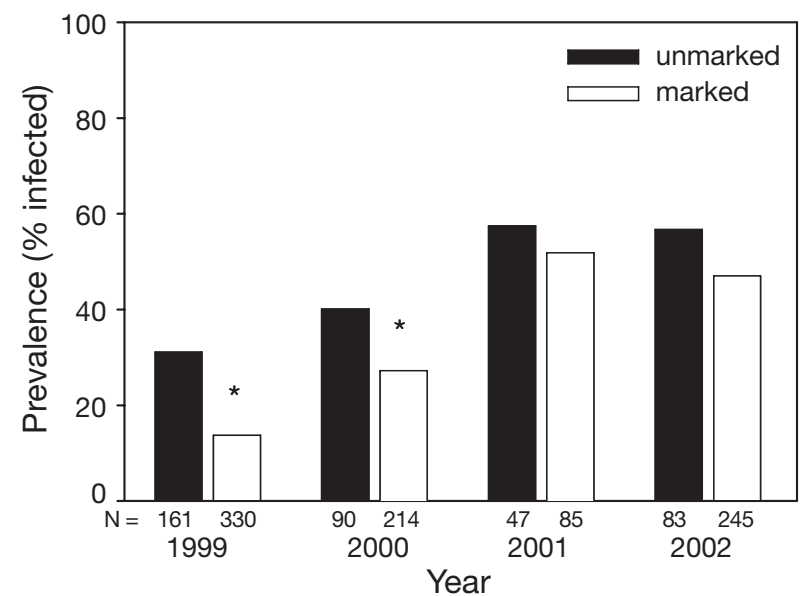

Fig. 6. Nanophyetus salmincola infecting Oncorhynchus tshawytscha. Prevalences of metacercariae in unmarked and marked yearling Chinook salmon caught off Washington and Oregon, USA. Marked salmon include salmon with any type of hatchery marking including clipped fins, coded-wire tags, PIT-tags, or colored latex markings. $\mathrm{N}=$ number of salmon examined for each period. ${ }^{*}$ Statistical differences $(p<0.05)$

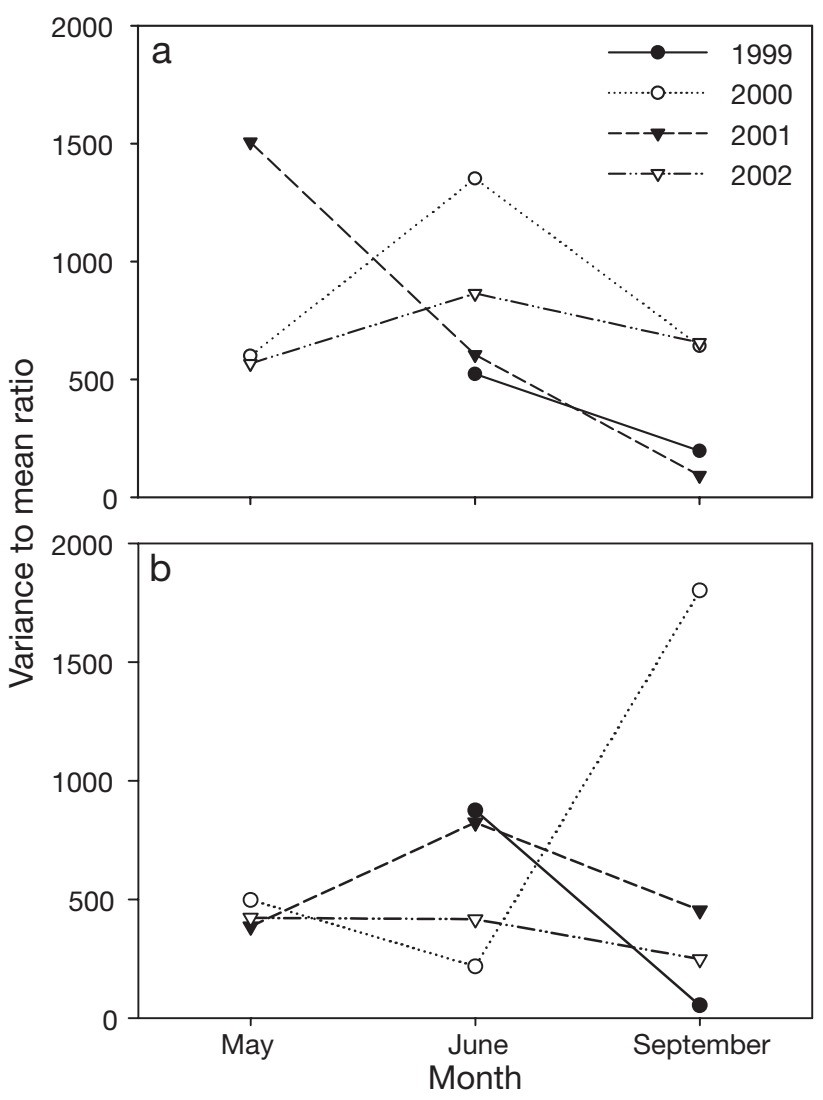

Fig. 7. Nanophyetus salmincola infecting Oncorhynchus kisutch. Variance to mean ratios of metacercariae abundance in (a) unmarked and (b) marked yearling coho salmon caught off Washington and Oregon, USA. Marked salmon include salmon with any type of hatchery marking including clipped fins, coded-wire tags, PIT-tags, or colored latex markings length ${ }^{3}$ ). Infection with $N$. salmincola also had no apparent effect on ocean growth rate of fish as estimated from average scale spacing of all ocean circuli, nor the last 2, 3,4 , or 5 circuli at the scale margin, in marked and unmarked coho salmon in June or September.

\section{Microsatellite DNA analysis of yearling coho salmon}

To determine whether seasonal differences in the prevalence of Nanophyetus salmincola could have been due to differences in geographic origins of coho salmon, the prevalences of $N$. salmincola in yearling coho salmon each month were analyzed by genetic stock assignments (Van Doornik et al. 2007). When the coho salmon were separated by stock assignment, the prevalences of $N$. salmincola were again significantly lower (15 to 29\% less) in September (Fisher's exact test, $\mathrm{p}<0.05$ ) than in May or June for each geographic area of origin (Fig. 8). Unfortunately, sample sizes were too small to be informative when the data were stratified by both genetic stock assignment and the presence or absence of hatchery markings.

\section{DISCUSSION}

The 4 years of data presented here supply evidence that the parasite Nanophyetus salmincola plays a significant role in early marine survival of juvenile salmon and affects the proportion of adult salmon that will

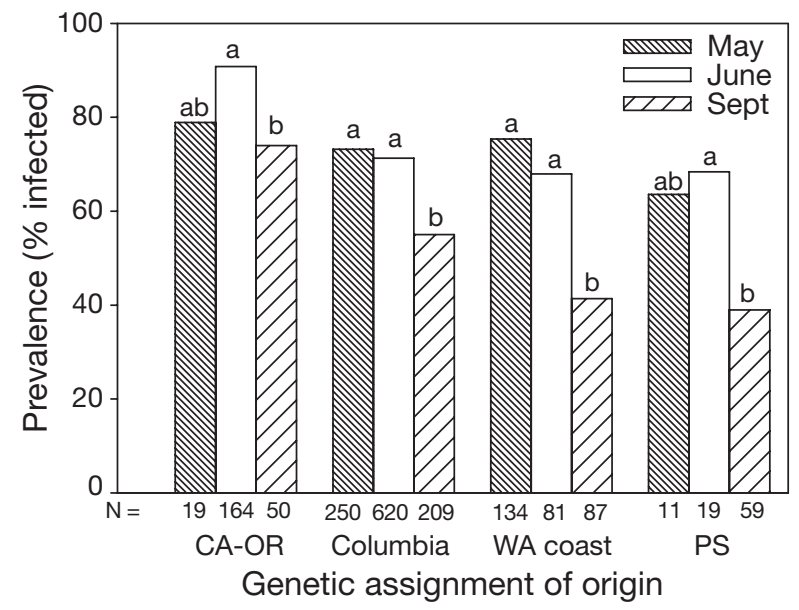

Fig. 8. Nanophyetus salmincola infecting Oncorhynchus kisutch. Prevalences of metacercariae in yearling coho salmon caught off Washington and Oregon, USA, separated by genetic stock assignment to region of origin. Regions of origin are California and Oregon coastal (CA-OR), Columbia River, Washington coastal, and Puget Sound (PS). N = number of salmon examined for each sampling period. Different letters indicate significant differences $(\mathrm{p}<0.05)$ between months (all years pooled) within a single region of origin 
return to spawn. Lower parasite prevalences, intensities, and dispersion in juvenile coho salmon caught in September compared to May or June suggest that parasite-associated host mortalities occur during early marine residence. Prevalences and intensities of the trematode in yearling and subyearling Chinook salmon were significantly less than those observed in coho salmon, and temporal differences in infection in either group of Chinook salmon were minimal. It may be that levels of infection in Chinook salmon were not high enough to affect early marine survival.

The lower infection levels in Chinook salmon than coho salmon could be due to differences in susceptibility to infection, but to our knowledge this has not been tested. Differences in freshwater habitat use between the 2 salmonid species (reviewed by Healy 1991, Sandercock 1991) could also affect parasite transmission and result in differences in infection levels. Chinook salmon fry emerge earlier than coho salmon, grow larger sooner in the year, and move downstream more quickly. Yearling Chinook salmon that overwinter in larger rivers often move out of the tributary streams into the mainstem river (Healy 1991). In contrast, coho salmon fry congregate in quiet backwaters, side channels, and small creeks, in pools or riffles close to a gravel bottom (Sandercock 1991). These behavioral differences in freshwater could result in greater exposure of young coho salmon to free-swimming cercariae of Nanophyetus salmincola as the abundance of the snail host is greater on gravel and cobble substrates than on sand or silt (Diamond 1976).

Changes from high to low infection levels in coho salmon indicated that many heavily infected yearling coho salmon off Oregon and Washington do not survive their first summer of ocean residence. In 3 of the 4 years of the study, the prevalence of Nanophyetus salmincola in yearling coho salmon was approximately $21 \%$ less in September than in May or June. In the only year in which this was not noted, 2001, the number of metacercariae in infected juvenile coho salmon caught in September was significantly less than in June, indicating that although the prevalence of infected coho salmon was high, those remaining infected coho salmon had few parasites.

The temporal pattern in the variance to mean ratio of metacercariae in coho salmon provided further evidence of parasite-associated mortalities during the summer. As with other fish-metacercariae systems, alternative mechanisms that could cause this temporal pattern of infection, such as age-related changes in the rate of infection, resistance to infections, or mortality of the parasites in the host, can be eliminated (Anderson \& Gordon 1982). After the salmon leave freshwater they are no longer exposed to the parasite; thus age-related changes in the rate of infection, or resistance to infection after leaving freshwater, do not occur. Also, the metacercarial stage of the parasite remains viable throughout the life of the salmon, and the number of metacercarial cysts does not decline in individual fish (Farrell et al. 1964). Thus, the observed decreases in the variance to mean ratio of Nanophyetus salmincola metacercariae over the summer months in juvenile coho salmon also suggest parasite-associated host mortality.

Similarly, Gordon \& Rau (1982) showed evidence for mortality induced by metacercariae of the trematode Apatemon gracilis in brook sticklebacks Culaea inconstans between mid May and late October. Lemly \& Esch (1984) confirmed parasite-induced host mortality caused by metacercariae of Uvulifer ambloplitis on young-of-the-year bluegill Lepomis macrochirus using both laboratory and field studies. They demonstrated that the most heavily infected bluegill were not able to overwinter due to depleted lipid reserves, ultimately eliminating 10 to $20 \%$ of the juvenile bluegill population each winter. In addition, Kalbe et al. (2002) noted parasite dispersion patterns over a 6 mo period in three-spined sticklebacks Gasterosteus aculatus that indicated parasite-induced host mortality as a consequence of a combination of parasite species.

It is also possible that the low levels of infection we observed in September in coho salmon were due, in part, to an immigration of juvenile coho salmon from beyond the enzootic region of Nanophyetus salmincola and not parasite-associated mortality. However, the overall stock composition of coho salmon for each month sampled changed very little (Van Doornik et al. 2007). In addition, when the coho salmon were split into their geographic region of genetic stock origin based on microsatellite DNA analysis, the same patterns of temporal decline in infection were observed in each stock group. Thus, the DNA analysis suggests that observed declines in infection levels in coho salmon were not due to migration of uninfected salmon from watersheds free of $N$. salmincola.

The overall prevalence and the temporal decline in prevalence of Nanophyetus salmincola, were similar in unmarked and marked coho salmon. However, the unmarked coho salmon, which had significantly higher intensities of $N$. salmincola than marked coho salmon, exhibited the greatest decline in infection intensities during early marine residence. Given that a large proportion of the unmarked coho salmon are naturally produced, the higher intensities of metacercariae noted in naturally produced coho salmon versus hatchery produced salmon could have resulted from greater exposure to the infective stage of the parasite in freshwater. It is also possible that infected hatchery produced coho salmon with parasite intensities as high as naturally produced coho salmon were removed from the population prior to ocean entry. 
We found no effects of infection on salmon growth and condition in any groups of salmon. Reported effects of other parasitic infections on fish growth and condition have been mixed. For example, parasitic copepods have been reported to impair growth of Atlantic salmon (Birkeland 1996), whereas suppression of growth in Loma salmonae infected rainbow trout was only temporary (Speare et al. 1998). In contrast, increased growth rates have resulted from infection with the tapeworm Schistocephalus solidus in laboratory-reared three-spined stickleback (Arnott et al. 2000).

Although we did not observe a negative effect of Nanophyetus salmincola on growth or condition of the salmon in our study, experimental studies have shown that this parasite can negatively affect several critical physiological and behavioral responses of juvenile Pacific salmon important for survival. Milleman \& Knapp (1968) noted a decreased growth rate of coho salmon $(1.5 \mathrm{~g})$ following exposure of up to 225 cercariae daily for $24 \mathrm{~d}$, but Amandi (1977) found no effect of infection on growth of larger coho salmon (2.2 to $3.6 \mathrm{~g})$ or steelhead Oncorhynchus mykiss. The swimming performance of coho salmon (57 to $60 \mathrm{~mm} \mathrm{FL)}$ can be impaired as much as $95 \%$ following exposure to 1500 metacercariae (Butler \& Millemann 1971). Also, laboratory infections of 257 to 543 metacercariae impaired immune function and increased susceptibility to the marine pathogen Listonella anguillarum in subyearling Chinook salmon (100 mm mean FL) (Jacobson et al. 2003). It is possible that our measures of early ocean growth are not sensitive enough to capture a population-level effect caused by $N$. salmincola infection. Alternatively, N. salmincola metacercariae may not affect early ocean growth but rather other key physiological or behavioral responses. Salmonids serve as the intermediate host for N. salmincola, with the parasite requiring consumption by a fish-eating bird or mammal for completion of its life cycle, so from an evolutionary perspective, increased risk of predation would be a likely result of infection in salmonids. In support of this, the negative effects of parasitic infection on fish swimming performance (Butler \& Millemann 1971, Blake et al. 2006) could lead to increased predation.

Pacific salmon encounter a suite of biological and physical conditions in freshwater, estuarine and marine environments that can affect the dynamics of this host-parasite association. The observed interannual differences in the prevalence and intensity of Nanophyetus salmincola in yearling salmonids are evidence of the influence of these environmental factors. In 2001, for instance, only the intensity of infection in coho salmon was significantly different between months, whereas in 2002, only the prevalence was sig- nificantly different between months. Spring and summer Columbia River flows varied significantly between 1999 and 2002, and river flows in the drought year of 2001 were less than half of those measured in 1999 (Emmett et al. 2006), affecting riverine, estuarine, and the Columbia River plume habitats. Low river flows, high temperatures, and a small plume could be related to the observed low intensities of $N$. salmincola by contributing to mortalities of highly infected fish prior to our sampling. Alternatively juvenile salmon could have spent less time that year in freshwater, diminishing their exposure to the parasite.

All measures of Nanophyetus salmincola infection in this study suggest that the first summer at sea is a period of parasite-associated mortality for coho salmon. With additional years of sampling, we will examine trends between infection, environmental conditions, and adult returns. Future studies will address ocean conditions that are likely to affect the health and behavior of juvenile salmon, the dynamics of this hostparasite interaction, and the survivability of infected Pacific salmon. The present study has clearly documented that parasites play an important role in the survivability of juvenile Pacific salmon in the marine environment and warrant further consideration as a factor affecting Pacific salmon returns.

Acknowledgements. We thank the captains and crews of the RV 'Ricker' and FV 'Sea Eagle' for their expertise in sampling of juvenile salmonids. We also thank the many scientists from NOAA's Northwest Fishery Science Center and Oregon State University who provided assistance in collection and dissection of the salmon. Special thanks to J. Fisher and B. Beckman for analysis of the data with growth metrics, and to C. Morgan for help with mapping and database management. R. Baldwin, R. Emmett, R. Olson, L. Weitkamp, and anonymous reviewers provided many helpful comments. This study was funded by the Bonneville Power Administration and the National Marine Fisheries Service.

\section{LITERATURE CITED}

Amandi A (1977) Effects of Nanophyetus salmincola, the salmon poisoning trematode, on growth and hematological characteristics of coho salmon and steelhead trout. $\mathrm{PhD}$ dissertation, Oregon State University, Corvallis, OR

Anderson RM, Gordon DM (1982) Processes influencing the distribution of parasite numbers within host populations with special emphasis on parasite-induced host mortalities. Parasitology 85:373-398

Arkoosh MR, Clemons E, Kagley AN, Stafford C and others (2004) Survey of pathogens in juvenile salmon Oncorhynchus spp. migrating through Pacific Northwest estuaries. J Aquat Anim Health 16:186-196

Arnott SA, Barber I, Huntingford FA (2000) Parasite-associated growth enhancement in a fish-cestode system. Proc R Soc Lond B 267:657-663

Bakke TA, Harris PD (1998) Diseases and parasites in wild Atlantic salmon (Salmo salar) populations. Can J Fish Aquat Sci 55:247-266 
Birkeland K (1996) Consequences of premature return by sea trout (Salmo trutta) infested with the salmon louse (Lepeophtheirus salmonis Kroyer): migration, growth, and mortality. Can J Fish Aquat Sci 53:2808-2813

Blake RW, Kwok PYL, Chan KHS (2006) Effects of two parasites, Schisotcephalus solidus (Cestoda) and Bunodera spp. (Trematoda), on the escape fast-start performance of three-spined sticklebacks. J Fish Biol 69:1345-1355

Bourque J, Dodson JJ, Ryan DAJ, Marcogliese DJ (2006) Cestode parasitism as a regulator of early life-history survival in an estuarine population of rainbow smelt Osmerus mordax. Mar Ecol Prog Ser 314:295-307

Bush AO, Lafferty KD, Lotz JM, Shostak AW (1997) Parasitology meets ecology on its own terms: Margolis et al. revisited. J Parasitol 83:575-583

Butler JA, Millemann RE (1971) Effect of the 'salmon poisoning' trematode, Nanophyetus salmincola, on the swimming ability of juvenile salmonid fishes. J Parasitol 57: 860-865

Dawley EM, Ledgerwood RD, Jensen A (1985) Beach and purse seine sampling of juvenile salmonids in the Columbia River estuary and ocean plume, 1977-1983, Vol I. NOAA Tech Rep NMFS F/NWC-74

Diamond JM (1976) The population dynamics and reproductive strategy of the stream snail Oxytrema silicula (Gould) in relation to stream order. MS thesis, Oregon State University, Corvallis, OR

Duerr HP, Dietz K, Eichner M (2003) On the interpretation of age-intensity profiles and dispersion patterns in parasitological surveys. Parasitology 126:87-101

Emmett RL, Krutzikowsky GK, Bentley P (2006) Abundance and distribution of pelagic piscivorous fishes in the Columbia River plume during spring/early summer 1998-2003: relationship to oceanographic conditions, forage fishes, and juvenile salmonids. Prog Oceanogr 68: $1-26$

Farrell, RK, Lloyd MA, Earp B (1964) Persistence of Neorickettsiae helminthoeca in an endoparasite of the Pacific salmon. Science 145:162-163

Fisher JP, Pearcy WG (1995) Distribution, migration and growth of juvenile Chinook salmon Oncorhynchus tshawytscha, off Oregon and Washington. Fish Bull 93: 274-289

Fryer JL, Sanders JE (1981) Bacterial kidney disease of salmonid fish. Annu Rev Microbiol 35:273-298

Gordon DM, Rau ME (1982) Possible evidence for mortality induced by the parasite Apatemon gracilis in a population of brook sticklebacks Culaea inconstans. Parasitology 84: 41-47

Healey MC (1991) Life history of Chinook salmon (Oncorhynchus tshawytscha). In: Groot C, Margolis L (eds) Pacific salmon life histories. UBC Press, Vancouver, p 311-393

Hudson PJ, Dobson AP, Newborn D (1998) Prevention of population cycles by parasite removal. Science 282: 2256-2258

Jacobson KC, Arkoosh MR, Kagley AN, Clemons ER, Collier TK, Casillas E (2003) Cumulative effects of natural and anthropogenic stress on immune function and disease resistance in juvenile Chinook salmon. J Aquat Anim Health 15:1-12

Kalbe M, Wegner KM, Reusch TBH (2002) Dispersion patterns of parasites in 0+ year three-spined sticklebacks: a cross population comparison. J Fish Biol 60:1529-1542

Kennedy CR (1984) The use of frequency distributions in an attempt to detect host mortality induced by infections of diplostomatid metacercariae. Parasitology 89:209-220

Kocan R, Hershberger P, Winton J (2004) Ichthyophoniasis: an emerging disease of Chinook salmon. Oncorhynchus tshawytscha in the Yukon River. J Aquat Anim Health 16: $58-72$

Lemly AD, Esch GW (1984) Effects of the trematode Uvulifer ambloplitis on juvenile bluegill sunfish, Lepomis macrochirus: ecological implications. J Parasitol 70:475-492

Lester RJG (1984) A review of methods for estimating mortality due to parasites in wild fish populations. Helgol Meeresunters 37:53-64

Logerwell EA, Mantua N, Lawson PW, Francis RC, Agostini VN (2003) Tracking environmental processes in the coastal zone for understanding and predicting Oregon coho (Oncorhynchus kisutch) marine survival. Fish Oceanogr 12:554-568

Millemann RE, Knapp SE (1968) Epidemiology of 'salmon poisoning' disease. Prog Rep US Public Health Serv Res Grant Report No. 5R 0 AI-06599 for period ending 31 July 1968, p 49-54

Millemann RE, Knapp SE (1970) Pathogenicity of the 'salmon poisoning' trematode, Nanophyetus salmincola, to fish. In: Sniesko F (ed) A symposium on diseases of fishes and shellfishes. Am Fish Soc Spec Publ 5:209-217

NMFS (National Marine Fisheries Service) (2005) Endangered species act status of West Coast salmon and steelhead. Updated July 13, 2005. Accessed 26 Sep 2006 at www.nwr.noaa.gov/ESA-Salmon-Listings/Index.cfm

Olson RE (1978) Parasites of silver (coho) salmon and king (Chinook) salmon from the Pacific Ocean off Oregon. Calif Fish Game 64:117-120

Pearcy WG (1992) Ocean ecology of North Pacific salmonids. Washington Sea Grant, University of Washington Press, Seattle, WA

Rousset F, Thomas F, De Meeus T, Renaud F (1996) Inference of parasite-induced mortality from distributions of parasite loads. Ecology 77:2203-2211

Sandercock FK (1991) Life history of coho salmon (Oncorhynchus kisutch). In: Groot C, Margolis L (eds) Pacific salmon life histories. UBC Press, Vancouver, p 395-445

Scheuerell MD, Williams JG (2005) Forecasting climateinduced changes in the survival of Snake River spring/ summer Chinook salmon (Oncorhynchus tshawytscha). Fish Oceanogr 14:448-457

Scott ME, Dobson AP (1989) The role of parasites in regulating host abundance. Parasitol Today 5:176-183

Simms BT, CR Donham, Shaw JN (1931) Salmon poisoning. Am J Hyg 13:363-391

Speare DJ, Daley J, Markham RJF, Sheppard J, Beaman HJ, Sanchez JG (1998) Loma salmonae-associated growth rate suppression in rainbow trout, Oncorhynchus mykiss (Walbaum), occurs during early onset xenoma dissolution as determined by in situ hybridization and immunohistochemistry. J Fish Dis 21:345-354

Van Doornik DM, Teel DJ, Kuligowski DR, Morgan CA, Casillas E (2007) Genetic analyses provide insight into the early ocean stock distribution and survival of juvenile coho salmon (Oncorhynchus kisutch) off the coasts of Washington and Oregon. N Am J Fish Manage 27: 220-237

Weiseth PR, Farrell RK, Johnston SD (1974) Prevalence of Nanophyetus salmincola in ocean-caught salmon. J Vet Med Assoc 165:849-850 